\title{
South Korea
}

\section{Fear is a hard habit to break}

\author{
Roger du Mars
}

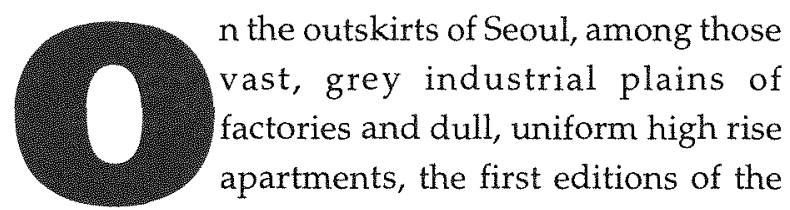
day's newspapers are being 'touched up' by senior editors, government officials looking over their shoulders. This is not censorship as most South Koreans understand it; having lived through military regimes so brutal that journalists were beaten, tortured and murdered for challenging totalitarian rule, and entire newspaper groups were unceremoniously swept up by the power holders. As we begin the 21st century, South Korea presents a democratic face to the world, government officials 'hint', 'request', 'entreat' or even 'cajole' editors into self-censoring sensitive articles. That this is tolerated points to the history of the media in South Korea: fear of authority, say journalists, is a hard habit to break.

After decades of authoritarian rule, South Korea has a largely tame media, unaccustomed to challenging the power brokers and, in many ways, professionally ill-equipped for their role in the democratic system. While blatant government control has been removed, new forces are threatening press reform while it is still in its infancy and, therefore, most vulnerable. Media ownership is concentrated in very few hands and business interests can fill the vacuum left by the state. At the same time, the government seems to be finding more sophisticated ways of managing editorial directions-the latest, a series of aggressive tax evasion investigations of executives of newspapers critical of the President.

\section{Struggling to find the right path}

After decades of strict censorship which reduced the press to a convenient mouthpiece of the dictators of the day, the media in South Korea is evolving 
towards genuine democratic standards. Stories critical of the government no longer attract the violent attentions of the secret police, nor do they precipitate phone bugging or harassment. Since President Roh Tae Woo repealed the notorious Basic Press Law in 1987, censorship laws have been removed from books. Apart from the National Security Act, there are few laws that can interfere with the dissemination of information. If newspapers steer clear of pro-North Korea stories, journalists and editors can expect to publish almost anything without fear of being jailed.

Official monitoring, however, continues despite the democratically reformed government. The extent of this monitoring and the ensuing censorship it produces is difficult to gauge. There are no defined 'untouchable' subjects, but government officials still actively monitor every issue of the major dailies. First editions are sent to the outskirts of Seoul where they are used as a 'rough copy' to be amended ahead of printing later editions. By and large there are no direct instructions to kill a story or change a headline: pressure nowadays is more personal, and moments of recalcitrance on the part of the media are tolerated.

'In the past the state restricted the media through repressive reporting guidelines. Now "private control" takes the place of overt restrictions. Government authorities call the media desks in private and coax them. They eventually persuade the media to accept a kind of self-censoring by using their private relationships,' says Lyu Eun-suk, of the human rights group Sarangbang.

Further undermining press freedom is the reality that Korean journalists are not accustomed to searching for news. Rather, they let the news come to them. The press releases issued by government ministries are typically regurgitated in the newspapers. Government policies questioned by reporters are usually those which have already attracted public opposition, the media does not lead the scrutiny of the administration. Being willing to go out on a limb to challenge authority, or conducting extensive research in pursuit of the truth is rare. Exerting the minimum effort is not a stigma in Korean journalism. Korean articles, frequently short exercises in stilted, formal language, use limited background material and few direct quotes. The sources, unnamed more often than not, are complemented by the reporters' own opinions.

So superficially are many issues considered in the press that this restricted mode of reporting brings with it an intrinsic 'self-censorship'. 
Press release journalism is practised across the board. Public relations people working in the culture industry, the huge business conglomerates and other commercial sectors are all too willing to provide reporters with prewritten stories. Businesses take great care to cultivate amiable relationships with reporters. Perks, such as cash gifts (chonji) are sometimes used to strengthen the relationship. It is a mutually beneficial relationship - business has their tailored stories printed and reporters are provided with convenient access to material. Meanwhile, the public is deprived of professional journalism which attempts to analyse or discuss current affairs seriously.

The backdrop to South Korea's ideologically weak media industry is decades of war, military rule and colonial subjugation. Forty years of harsh Japanese colonial rule and 47 years of war or military rule have produced a media culture in which journalists still expect to submit to some kind of pressure from authority figures. While reporters are no longer tortured or killed for pursuing an independent line, the legacy of totalitarianism and the cultural overlays of Confucianism run deep. In The Unfolding Lotus, Jon Vanden Heuvel and Everett E. Dennis argue there is little incentive for South Korean journalists to pursue the news aggressively.

The pressure on journalists to blend into the establishment fabric cannot be underestimated. This coziness between those in power and the press is tolerated and even encouraged because it does not seem the least bit unnatural to most Koreans. Theirs is a very homogenous, Confucian society, where harmony, cooperation and consensus between the powers that be and the press are more valued than a journalist's exposés of injustices and individual bravado. In the pantheon of Korean journalism there is little investigative reporting in the US style of Bob Woodward and Carl Bernstein of Watergate fame (1993).

The paths leading into the journalism profession tend to reinforce a culture of bowing to authority and fitting in with the system, rather than breaking new ground. The field is extremely competitive, with about ten jobs for every 1,000 applicants. Entering the profession is about as difficult as entering one of the country's most prestigious universities. As a result, applicants with strong general knowledge, good writing skills and foreign languages win the entry-level jobs. However, the best academic qualifications do not necessarily equip young journalists to seek out the truth. South Korea's education system is highly conformist and reflects 
the community values-it does not seek to produce graduates who question that system. 'Today's journalist is not very much of a true journalist who is charged with a public mission', says Chung Yeon-woo, assistant professor of advertising and media at Semyung University. 'He is just a salaried man who has to make a living. Journalists need to be more professional and to have more dignity.'

Working within the establishment and writing inoffensive stories cultivates another form of self-censorship when reporting on foreign news. For example, stories on Japan invariably conform to Korea's view of the Japanese as unrepentant oppressors. When Kwon Hee-ro, the Korean who in 1968 killed two Japanese gangsters who called him a 'little dirty Korean pig', was released from prison and returned to South Korea in September 1999, not one newspaper suggested that murder was an inappropriate method of protesting discrimination. The press unanimously joined the national celebration for this hero who valiantly raised awareness of the cruelty, and arrogant superiority, of the Japanese. If the media defines the perimeters of the news, the public's perception of daily events, too, seems to be trapped within this limited range of reporting.

\section{A century of oppression, a decade of freedom}

Notwithstanding the democratic reforms of the past 12 years, the people of South Korea have been victims of successive, oppressive governments for much of the 20th century. The Japanese effectively usurped control of the government in 1905 when it made Korea a protectorate. After formal annexation in 1910, the Japanese exercised unremitting and brutal authority over the neighbours they considered an inferior race. The end of World War II drove out the Japanese, but opened the way for the establishment of Soviet Communism, gaving birth to the Stalinist regime of Kim II-Sung which occupied the northern half of the Korean Peninsula. Two years later the Korean War devastated this relatively small and crowded stretch of territory. The division between the North and South at the 38th parallel remains to this day, with the two Koreas each bidding warily for reunification on its own terms and enduring the ever present threat of each other's military and intelligence apparatus.

Throughout decades of threats to stable government and the severe poverty and famine which followed the Korean War, a free media was 
consistently viewed as a potentially destabilising influence that the fragile society could not support. With no historical tradition of democratic principles in South Korea, the media has never had the opportunity to blossom within the intrinsic principles of freedom. 'While the notion of the freedom of the press and of democracy have literally evolved hand to hand in the west, the South Korean media have lacked such an institutional foundation', notes Lee Jae-kyoung, professor of journalism at Ehwa Women's University in Seoul. 'Simply put, the idea of the free press in South Korea was nothing more than a superficial imposition of a foreign idea which completely lacks indigenous institutional support' (1993a:6).

The United States, which tried to establish law and order in South Korea following World War II, imposed US press concepts that never took root and were only ever in force theoretically. An ordinance designed to promote a free press in 1946 was simply too advanced for such an insecure country. 'As of today all the laws and decrees with legal authority shall be rescinded if their judicial and administrative applications result in discrimination because of race, nationality, creeds or political beliefs' (Youm Kyo-ho 1996:38). Designed to set Koreans free from the harsh yoke of the Japanese, such laws invariably crumbled under the more pragmatic realities of wielding political power in a starving, chaotic land.

When South Korea's first president, Syngman Rhee, guaranteed freedom of expression as a basic constitutional right in 1948, for example, he promptly undermined the integrity of his own proclamation by issuing a set of tough decrees, ostensibly intended to protect South Korea from communist-inspired activities. The press was prohibited from publishing - articles which run contrary to the national ideals and policies of the Republic of Korea

- articles which defame the government

- articles which propagate and praise communism and the puppet regime of North Korea

- articles based on fabricated facts which agitate the general public

- articles which interfere with relations between the Republic of Korea and other friendly allies and that damage the national prestige of Korea

- articles that, in addition to inciting the people through provocative and radical editorials or reporting, affect the national unity harmfully

- articles that divulge the national secrets detrimental to the security of the Republic of Korea. 
So overwhelming were these restrictions that almost any controversial issue could be considered taboo.

During the Korean War of 1950-53 President Rhee upgraded restrictions with total military censorship of the Korean press. But after the war, the Rhee government, itself crippled by widespread official corruption, called on the National Security Act to prohibit 'problematic views'. A few anti-government newspapers, however, survived, fuelling public discontent and stoking the April 1960 student's uprising which toppled the Rhee administration. Under the shaky rule of Rhee's successor, Chang Myon, long-suppressed voices erupted into a rash of new newspapers. Ten days after Chang rescinded the laws stifling the press, 49 new media outlets were opened. News agencies increased 20 -fold and the number of daily newspapers tripled by the end of Chang's brief rule. But, press freedom did not necessarily bolster democracy. Bernard Lavine, former director of the United States Information Service recalls living in South Korea during Chang's brief foray as leader, 'when President Yun Bo-sun and his Prime Minister Chang Myon took control of the government in July 1960, it was a heady time for political "wanna be's", the press and other media. Unrestricted freedom for 10 months, which many Koreans understood to be democracy in action, created a chaotic situation which resulted in the military coup d'etat by Major General Park Chung Hee on May 16, 1961.'

Park immediately set out to 'purify' the Korean press. He spearheaded the Supreme Council for National Reconstruction which imposed standards designed to 'clean out those phony journalists and press which were catering to defile the sacred freedom of press, and to establish a fresh order in journalism and develop a truly democratic press' (Youm Kyo-ho 1996:12). This cleansing campaign included the arrest of 960 reporters and the closure of 1,200 news organisations, newspapers and periodicals. Government officials routinely dropped by newsrooms to check for unfavourable content. Under Park's 16-year authoritarian rule, journalists who took too many liberties were either thrown into prison, tortured or on occasion, even killed.

Under Park's military junta, the Revolutionary Court sentenced to death in August 1961 three executives of the Minjok Ilbo newspaper for 'advocating political and ideological doctrines similar to those of North Korea such as-neutralization of Korea, negotiations with the North 
Korean communists, exchanges of mail with North Korea and student meetings between North and South Korea' (Youm Kyo-ho 1996). One of the three was executed in December 1961. The other two had their sentences commuted to life imprisonment. In 1964, student protests were growing, culminating in massive demonstrations over Park's decision to restore diplomatic relations with Japan. Park blamed the upswing in street opposition on the media, which in turn demanded more freed om; opening a new confrontation between joumalists and the regime. Park's answer was the Press Ethics Commission, which added yet another raft of restrictions to the code of ethics for the Korean press.

Suppression of the press under Park seemed to intensify every few years. Journalists were required to carry government-issued press cards and access to information was confined to government offices. A series of Presidential Emergency Measures enacted in 1974, however, peremptorily mocked his ridiculous claims of support for a free press. The decrees prohibited criticism of the constitution, demonstrations and reporting on them, and the 'act to publish, produce, process, distribute, exhibit and sell papers, books, disks and other presentations relating to the National Federation of Democratic Youths and Students', an important student organisation which Park outlawed in April that year. The Dong-A Ilbo newspaper attempted to strike back, launching a free press movement on 24 October when it issued the Declaration of Freedom of the Press

The unprecedented crisis of our society, today can only be overcome through the practice of freedom of speech. There can be no reason to suppress freedom of speech which is the fundamental task we must fulfill. It is not a task which can be permitted by the government or granted by the people. We will never kneel to any pressure which comes from the opposition to free speech. We declare that we will do our best to practice free speech.

With these forceful words, the newspaper vowed to stand up to the formidable Korean Central Intelligence Agency.

Not surprisingly, Park responded by threatening the newspaper's advertisers. By January 1975, Dong-A Ilbo had lost 98 per cent of its advertising revenue. Supporters both within and outside South Korea tried to offset the losses by increasing circulation. But, Park dealt the finishing blow by sacking 133 of its reporters. The few remaining journalists who clung to the free press movement were imprisoned. 
As a business, however, the media actually expanded considerably under Park. Total newspaper circulation figures, nationwide, hovered around the three million mark in 1970. Ten years later this figure leapt to 6.2 million. Park's strategy was to expand the economy and in so doing he empowered a select group of businesses. From within this group of entrepreneurs he helped the media owners who helped him. A handful of newspapers which toed the official line thrived, while others which still attempted more independent reporting were systematically purged and forced to close. The increase in circulation figures reflected the overall growth in the economy as South Korea began to industrialise rapidly, rather than any improvement in the quality of the press. Professor Park Yeong-gyu at Sangji University observed at the time

The press has developed rapidly through all kinds of preferential treatments and benefits granted in exchange for accepting suppression. These pressures lead the press to join hands with the 'power brokers' and seek only profits. Naturally, the press lost their sense of duty and purpose, bringing about a distortion of public opinion and the suppression of civil rights.

\section{A false dawn}

Arguably though, the assassination of Park in October 1979 and the inauguration of his successor General Chun Doo Hwan ushered in an ever more repressive era for the media. Chun's constitution grossly belied the true state of affairs, stating 'All citizens shall enjoy freedom of speech and of the press, and freedom of assembly and association; neither speech nor the press shall violate the honour or rights of other persons nor undermine public morals or social ethics. Should speech or the press violate the honour or rights of other persons, claims may be made for the damage resulting therefrom' (Article 20(1)(2), amended in 1980). But such high-minded ideals were swiftly buried under Chun's paranoid, dictatorial regime.

No sooner had he declared himself President than he swiftly sacked 700 reporters and editors for indulging in unethical conduct or lacking proper journalistic abilities. With the elements most detrimental to a free and prosperous country out of the way, Chun proceeded to overhaul the entire media industry. He merged 27 daily newspapers into 21 , dumped 
the two commercial television networks, and added an additional staterun network. The hallmark of Chun's notorious clampdown on the media, the Basic Press Act, forced the media to adopt a set of practices that thoroughly adulterated the process of reporting, and shifted the engine of democracy into reverse at a time when it most needed to go forward. From the time it was enacted in December 1980 until it was repealed in June 1987, this draconian law not only extinguished the spirit and professionalism of the media, but caused diplomatic tensions between South Korea and critics in democratic nations.

Characterised by journalism scholar Lim Sang-won as 'one of the most restrictive and comprehensive laws in capitalistic societies', the Basic Press Act imposed complicated technical standards for publication facilities, preventing the growth of existing newspapers and the opening of new publications. It turned what the government defined as the 'responsibility' of the press into a legal obligation; gave the whip to the Ministry of Culture and Information which issued press guidelines instructing the media on how events should or should not be reported. Headlines were selected by the Ministry as were article lengths and the pages where they could be printed. The Ministry also limited the number of pages newspapers could print and determined which correspondents were stationed in provinces outside of Seoul. The Ministry retained the right to suspend or close any publication, radio or television station at any time.

In reality, the Basic Press Law was seldom employed, nor was it ever challenged in court by the journalists, editors or proprietors it controlled. "The fact that the law was never challenged in court demonstrated how the judicial system had forfeited its role as the guardian of the Constitution and how effectively the press itself had been cowed', says journalism scholar Chang Hosoon. Afraid of offending the government, the press became even more removed from any concept of responsibility in reporting the daily news. Chun also frequently employed the Korean Army Security Command and the Korean National Security Planning Agency (formerly the Korean Central Intelligence Agency) to intimidate and, occasionally, force the press to submit to its demands. When the Chosun Ilbo took the risk of reporting on opposition politician Kim Young-sam's hunger strike, for example, KNSPA agents harassed the political reporter who wrote the story, pressuring other reporters not to continue to follow the issue. 
According to a report issued by the International Press Institute, the KNSPA literally beat into submission the Dong-A Ilbo. In reporting on the Chinese H-5 bomber which crash-landed in Korea on 24 August 1985, the newspaper contradicted official announcements when it noted that Korean fighter planes failed to intercept the Chinese aircraft. Embarrassed by the revelation and livid over Dong-Allbo's rash decision to break a government news embargo on a 'diplomatically sensitive' issue, KNSPA Director Chang Se-dong hauled in the newspaper's managing director and two other journalists. Inside his office, Chang ordered his lieutenants to punish the three men physically. They left the office severely beaten and less eager to defend high journalistic ideals. The Dong-A Ilbo also agreed not to run a story on the KNSPA's intimidation tactics.

A good example of Chun's control of the media resulted in widespread confusion over the truth about the Kwangju incident, arguably the most tragic and controversial event since the Korean War. What started as routine street demonstration on 18 May 1980, deteriorated into violent clashes between the citizens of Kwangju and the military. The masses, who took up home-made arms, managed to rule the streets of the city for about a week. To regain control, the military unleashed a wave of terror, killing at least 200 civilians. In his dissertation, Anti-Americanism in South Korea: The Media and the Politics of Signification, Lee Jae-Kyoung describes how Chun deceived the public.

The reporting of the Kwangiu incident was under the control of the military regime. In fact, it seems that every major editorial decision was made and enforced by the military censors, and the media were simply reduced to propaganda organs of the regime. The South Korean media completely neglected even the occurrence of this extraordinary incident for nearly four full days, indicating well the intensity of the regime's media control. Every major news item, from the top frontpage story to entries in the society and cultural sections, including editorials, bylined columns and comments, was meticulously screened, placed and constructed to serve the military's political objectives (1993b:100).

Chun's blackout on the massacre instigated a rash of anti-American sentiment that continues to linger today. Many Koreans were expecting the United States, which has maintained significant military bases in South 
Korea, to intervene on the side of the people. Regardless of the validity of these expectations, the absence of US intervention was interpreted in some quarters as categorical proof that Washington supported Chun and that the US government was actively plotting to control Korean society to serve the interests of US citizens at the expense of Korean liberties. A document issued by the US embassy in Seoul explains

It is clear that one cause of increased anti-Americanism in Korea in the 1980 s is the false impression held by many Koreans that the US was directly involved in, and significantly responsible for the Kwangju tragedy-a misperception in part fostered by the deception of the Korean authorities at the time, and in part by the restriction on the dissemination of facts about the Kwangju incident during the Fifth Republic (Backgrounder, 19 June 1989:26).

\section{New freedoms, old habits}

In the summer of 1987, the streets of Seoul were filled with the sting of tear gas and the pounding of military boots. Day after day, highlyorganised student protesters faced down the ranks of anti-riot troops, their own sense of courage preventing them from donning the gas masks which protected the security forces and the swarms of foreign reporters from the suffocating clouds of tear gas. Some smeared their faces with toothpaste and wrapped their eyes with 'cling wrap', innovations of the mass protest movement. But, among the students stood ordinary citizens and many of the students' mothers, their hand bags swinging, their twin sets buttoned to the neck; a sign the regime had truly lost its power. Finally, with two million people on the streets backing the student protests, the city was paralysed, and the government squirming uncomfortably in the international spotlight as the upcoming host of the 1988 Olympic Games, Chun was forced to step down. Chairman of the ruling Democratic Justice Party and presidential candidate, Roh Tae Woo, was handed control, vowing to break Korea's 'cycle of authoritarian rule' despite his own military roots. Roh, who went on to serve as president from 1988-92, was in many ways as corrupt as his predecessor. But, in terms of press freedom Roh took the first steps towards a new era.

Roh got off to a promising start when the Basic Press Law was repealed in November of 1987, and the new liberties he granted the media made 
his administration seem like a shining light of democratic principles. But, for three decades the press had been an integral part of a corrupt and authoritarian power structure and so thoughtful, honest reporting could not spring up overnight. Himself a past master of taking bribes, Roh nonetheless proclaimed an end to envelope journalism. The practice of chonji reached its height during Chun's rule but seems to have steadily waned thereafter. In a press survey of 700 journalists conducted by the Korean Press Institute in 1989, 93 per cent of the respondents said they received bribes from their news sources. But five years later, another survey showed that this figure had dropped to less than 30 per cent and today most reporters say the practice is uncommon.

But, some reporters continue to be hooked on the white envelopes, and have resorted to extortion to have their 'benefits' reinstated. In just three months, from May 1998 to July 1998, the Ministry of Culture alleged 43 journalists were involved in 70 cases of extortion. In these cases, journalists typically approach a company with scandalous information which they threaten to expose if they are not given chonji money.

Roh's reforms, while far from sweeping, were nonetheless sufficient to produce an atmosphere in which ethically minded, liberal publications could prosper. In a signal that times had truly changed, a group of dissident journalists banded together and formed Han-kyoreh Shinmum, in December 1987, a completely new type of newspaper which not only prohibited the practice of taking chonji, but dared to adopt a left of centre political posture. After a lengthy struggle to obtain government approval and with its coffers filled with US $\$ 7$ million donations, Han-kyoreh published its first paper on 15 May 1988. Owned by citizen shareholders and written entirely in the Korean alphabet, hangul (as opposed to featuring the customary spattering of Chinese characters), the newspaper was founded as a grass roots publication that could empathise with North Korea, support opposition politicians and attack the Korean establishment.

While the mainstream press has remained reluctant to expose the malfeasance of the power élite, Han-kyoreh has come to represent a voice willing to challenge entrenched power structures.

Korean joumalists cannot shake overnight the habits acquired during decades of repression. There is still a tendency to avoid attacking someone in power, someone who could later exact revenge upon a troublesome reporter. For instance, during the 1992 elections, it became 
known that the central government and the Seoul city government were funneling money into the ruling Democratic Justice Party's election coffers. This blatant misappropriation of funds was largely ignored by the Seoul press, except for Han-kyoreh Shinmun, which ran the story (Vanden Heuvel and Dennis 1993:21).

\section{Broadcast joumalism under the government's thumb}

The government has always regarded broadcast media as the most powerful and influential medium and has consequently afforded it the least amount of freedom. The airwaves were strictly controlled under Park Chung-hee's dictatorial regime, Chun Doo-whan's Basic Press Law and Roh Tae-woo's Broadcast Act.

While the repeal of the Basic Press Law significantly freed up the print media with the Periodicals Act, the corresponding Broadcast Act of 1987 continues to constrain broadcast media to government-approved material. The three TV stations, two of which, KBS and MBC, are owned by the government, are still bound to the 'public responsibility' provisions of Broadcast Act to the 'improvement of national culture' and are prohibited from undermining public morality and social ethics.

Ever since the Broadcasting Law was amended in 1990, reforms were regularly debated. The integrated broadcasting law was finally passed by the National Assembly on 28 December 1999. The National Broadcast Labor Unions had frequently warned about the President's control over the commission to be established under the new law, which they said, should operate with autonomy, a measure of objectivity, and without undue foreign influence. The commission influences programming under the ostensible objective of promoting morality, free democracy, national identity, pure family life, proper guidance for children and social ethics.

The government naturally congratulated itself on the passage of the integrated broadcasting law. The opposition Grand National Party (GNP), however, boycotted the vote and complained of the ruling party unfairly setting up a censorship mechanism. Comprised of nine members, three selected by the president, three by the chairman of the parliament and three by the culture and tourism committee, the Opposition charges that the new commission will be under undue government control. 
'With the passage of the integrated broadcasting law, the government is still controlling the press,' says Chung Byung-joon, Secretary General of the Korean Federation of Press Unions. 'If the government is responsible and chooses good commissioners who have large capacities and talents, then there might be some progress. But the ideal is not happening yet. There is still a clear line linking the press and government authorities.'

The new broadcasting law settles a second controversial point concerning outside investment. The trade unions had lobbied vigorously to prevent foreigners and the chaebol from investing in the media. The Ministry of Information and Communication had insisted that foreign capital and expertise were necessary to make competitive the range of new media, such as satellite-based, digital and cable TV, and optic cable projects. The new law restricts foreign firms and the chaebol from owning more than a 33 per cent stake in local media companies. With the door thus open for joint ventures, cash and technology are expected to stimulate the industry.

Launched in 1995, the nation's 28 cable TV channels have racked up losses in the neighborhood of US $\$ 1$ billion. With only 830,000 subscribers, paltry advertising revenues, numerous operators are teetering on the verge of bankruptcy. Says Eom Ju-woong, Director of the People's Coalition for Media Reform: 'The censorship has changed from direct to indirect but with the government still controlling the media and intervening, it's even more important to have citizens participate in the political process'.

\section{Where to from here?}

The establishment press is chiefly owned by Korea's behemoth business conglomerates called the chaebol. Long criticised for obvious conflicts of interests, two influential newspapers have apparently severed ties with the chaebol. South Korea's second largest chaebol, Hyundai, announced its managerial withdrawal from Munhwa Ilbo on 16 January 1998 and Samsung from JoongAng Ilbo on 21 January 1998. However, an informal survey indicates a skeptical public assumes the previous business relationships still exist. This is a particularly worrisome relationship because the power vacuum left by the authoritarian governments has been filled by big business. Kim Tak-hwan, senior researcher at the Korean 
Press Institute says, 'It cannot be denied that newspapers have been inclined to represent a particular group of business interests instead of representing public opinion, as collaborators of the powerful and not as watchdogs'.

The power of one particular business sector over the press was demonstrated in late 1997 as the full impact of the regional financial crisis was starting to take hold. The Maeil Kyungje, a local economic daily, reported that a major Seoul bank was virtually dry of funds, and published a special supplement examining Korea's banking industry. The first copies of the supplement news-stands in the late evening, causing many depositors to swarm into the bank's headquarters to protest. Later that evening, the members of the union of the bank stormed the offices of the newspaper.

In a more subtle form of control, South Korean governments have taken advantage of ubiquitous tax fraud to shadow the press. By threatening to conduct tax audits on individual newspapers or their companies, the government finds plenty of editors all too willing to allow the government to influence content.

Since the repeal of the Basic Press Law media analysts agree that South Korea has been moving steadily towards freedom of the press. However, recent accusations levelled against the incumbent administration hark back to the dark past. A vocal critic of the present Kim government, the Segye Times-run by Rev. Moon Sun-myong of the Unification Church-was recently the subject of a special tax audit. Then, there is the friction between a popular daily, the JoongAng Ilbo and the South Korean government, which points to a more troubling case of media autonomy being short-circuited by the ruling administration. In September 1999 a tax audit was ordered on the sundry financial operations of Hong Seok-hyun, publisher and president of the JoongAng Ilbo and the largest shareholder of the Bokwang Group. Prosecutors arrested Hong for evading 1.33 billion won in taxes by failing to report 3.23 billion won inherited from his mother; evading 950 million won in taxes on 79,000 shares that he received from three executives from former Samsung executives; and evading another 50 million won by understating the amount he paid for 20,000 shares of an electronics firm. The JoongAng Ilbo claims its regular reporting on the scandals that have dogged the administration eventually landed it in hot water. 
Suspicious of the government's motives in taking the unusual move to carry out the probe, the International Press Institute fired off a letter to the Government Information Agency which states

If our sources of information are correct, there have been several audits of the Bokwang Group over the past years, the most recent one in 1997, which ended with a clean bill of health... The tax probe which started on 29 June 1999, was not a routine one, since without prior noticeapproximately 50 tax officers searched the company and confiscated its accounting books...Since the case is now in the hands of the prosecution, we do not see any legal grounds for an arrest and detainment, as all confiscated material is available to the prosecuting attorney's office anyway; the danger of suppressing relevant evidence is minimal and there is certainly no danger that the accused person would try to escape out of the country (Korean law prevents such an attempt by requiring exit visas). We agree that it is a democratic principle for legal investigations of irregularities or violations of law to be applied to every citizen equally. A publisher or president of a newspaper is no exception to that. However, a fundamental legal principle holds that a person is innocent until proven guilty by the courts.

But, the case is more complicated than it may seem. Tensions between the JoongAng Ilbo and Kim Dae-jung began escalating when he was campaigning for the 1997 presidential elections and believed the newspaper was unfairly supporting his opponent, Lee Hoi-chang. Reports circulated that money had illicitly flowed from Lee's campaign war chest to the coffers of either the Joong-ang Ilbo or the Samsung Group, the huge conglomerate that owned a major stake in the newspaper. The various rumours are difficult to confirm. But, what is evident is that neither the newspaper nor the government regards each other as neutral.

The prosecution pressed for a six-year term and a 5.1 billion won fine shortly after Hong Seok-hyun was arrested in October. When the Seoul District Court meted out a suspended 3-year sentence and a 3.8 billion won fine, the opposition Grand National Party (GNP) accused the government of cutting a deal with the JoongAng Ilbo.

'The JoongAng Ilbo had a plan to make an all-out assault on the government after Hong Seok-hyun's arrest in order to get the Kim Daejung administration to back off', said a member of the GNP. 'As far as I 
see, the plan only partly worked because the prosecution tried to get a severe punishment and the judge gave him a major fine.'

Consequently, Lee Hoi-chang, leader of the opposition Grand National Party, claims JoongAng Ilbo is waging a struggle to protect the freedom of the press. The GNP launched a special in-house panel to break up 'increasing government repression of the press', and submitted a dismissal motion to the National Assembly against Culture and Tourism Minister Park Jie-won, a former spokesman for President Kim who allegedly pressured the JoongAng Ilbo to tone down its criticism of the government. The GNP has also accused Mr Park of trying to influence major staff appointments at the paper, control the treatment of stories and intimidating Mr Hong by throwing a glass at him. During the National Assembly's annual policy evaluation meeting in early October, Mr Park explained his actions, 'As I drank a lot that night, there are some things I can remember and some things I cannot'.

President Kim Dae-jung insists there is no relationship between the attention the National Tax Administration and his public relation officials are giving to the JoongAng Ilbo and an attempt to control the media. 'This government of the people respects freedom of the press and it never intends to suppress the press', he says.

If the rift between the JoongAng Ilbo and the Kim Dae-jung administration simply centered on allegation of the government pressuring the press to toe the line, the conflict would simply fall into a long tradition of Korean authoritative practices. But the conflict takes on the trappings of an all too common political drama, rife with stealth and multiple accusations, all difficult to verify.

For all the antipathy marking the relationship, it seemed initially peculiar that a JoongAng Ilbo reporter was accused of trying to help the Kim Dae-jung Administration. In November, Moon Il-hyun, on the apparent behest of the ruling coalition, faxed to Lee Jong-chan, Vice President of the NCNP, a list of suggestions designed to help the ruling party gain more public favour. The suggestions covered various ways in which the government could exploit the press to encourage the public to muster support for Kim Dae-jung's reforms.

The plot thickened when Lee Do-joon, a reporter for Pyonghwa Broadcasting Corp. visited Lee Jong-chan's office, discovered the letter, turned it over to GNP lawmaker Chung Hyung-keun who paraded it at a 
National Assembly hearing as evidence of the president manipulating and controlling the media.

The GNP found more fodder for its offensive when rumors spread that President Kim had received illicit contributions from the JoongAng Ilbo. While apparently intoxicated, National Intelligence Service chief Chun Yong-taek told reporters 'off the record', that Hong Seok-hyun had indeed supplied Mr Kim with secret political funds prior to his presidency.

Issues such as hidden motive and shifting alliances sparked much speculation. The rival parties exchanged accusations, the public assumed the worst and numerous questions remain unresolved. Such is the state of politics and the media in South Korea.

\section{Media websites}

Chosun Ilbo, www.chosun.com/

Dong A llbo, www.dongailbo.co.kr/

Han'guk Kyeongje Sinmun, www.ked.co.kr/

Han'guk Ilbo, www.korealink.co.kr/

Ilgan Muyeok, www.tradenews.net/

JoongAng Daily News, www.joongang.co.kr/

Korea Economic Daily, www.joongang.co.kr/

Kyong-Hyang, www.khan.co.kr/

Munhwa Ilbo, www.munhwa.co.kr/

Seoul Shinmun, www.seoul.co.kr/ 